\title{
A Liberdade de Escolha em Bergson e Schopenhauer
}

\author{
Helio Lopes da Silva ${ }^{1}$ \\ Em memória de Bento Prado Jr.
}

\begin{abstract}
Resumo: Eu mostro neste artigo que Schopenhauer e Bergson, mesmo abordando o problema da ação livre a partir de pontos de vista filosóficos opostos, concordam em caracterizar as açóes humanas de um modo que não é nem determinista, nem compatível com a tese do liberum arbitrium. Schopenhauer, embora equivocadamente tente demonstrar a necessidade de tais ações, é obrigado a reconhecê-las como grundlos e imprevisíveis, enquanto Bergson, embora pretenda mostrá-las como sendo livres, ao final admite que elas não são objeto de uma escolha através da razão. Essa coincidência inesperada entre ambos os filósofos, a respeito do problema da liberdade da ação humana, será explorada neste texto.
\end{abstract}

Palavras-Chave: Schopenhauer. Bergson. Liberdade. Determinismo. Escolha. Previsão.

\section{INTRODUÇÃo}

É fácil constatar que Schopenhauer e Bergson ${ }^{2}$ abordam o problema do livre-arbítrio a partir de perspectivas filosóficas diferentes e mesmo opostas - para Schopenhauer, esse problema oferece uma oportunidade de mostrar como a sua Vontade metafísica, a qual é infundada, inexplicável e atemporal, tem todas as suas manifestações fenomenais estritamente submetidas ao e, portanto, tornadas necessárias pelo Princípio de Razão Suficiente. E, particularmente em seu ensaio premiado Sobre a Liberdade da Vontade, ele, executando esse programa, estará principalmente ocupado em rejeitar as pretensóes dos adeptos do livre-arbítrio, em demonstrar como cada ação particular do homem é o resultado necessário da incidência de um motivo sobre um determinado caráter. Para Bergson, ao contrário, o problema do livre-arbítrio oferece a oportunidade de evidenciar como a temporalidade ou duração pura da vida da consciência é o lugar onde se pode encontrar uma

\footnotetext{
${ }^{1}$ Hélio Lopes da Silva é Doutor em Filosofia (USP/1998), Mestre em Lógica e Filosofia da Ciência (UNICAMP/1991), Licenciado em Psicologia e Psicólogo (UNESP/1985), e Professor Associado da Universidade Federal de Ouro Preto/UFOP/MG, desde 1999, tendo recentemente (2013) concluído o Estágio pós-Doutoral na Universidade Federal de Minas Gerais (UFMG). E-mail: heliolopsil@bol. com.br http://dx.doi.org/10.1590/S0101-31732017000100003

2 Para as referências às obras de Schopenhauer, utilizaremos as seguintes abreviaçôes: WWV- Die Welt als Wille und Vorstellung. WWR- The World as Will and Representation. LV - On the Freedom of the Will.
} 
verdadeira criação, a criação de algo realmente novo, de algo que ultrapassa e é inapreensível pelas aspiraçóes mecanicistas da ciência. Sobretudo em seu Ensaio sobre os dados imediatos da consciência, Bergson estará preocupado em rejeitar as pretensôes dos deterministas, pretensões aglutinadas principalmente na ciência psicofisiológica da época, ao apontar que os conceitos mobilizados por tal ciência são incapazes de apreender a temporalidade pura característica da vida consciente. Apesar dessa oposição entre as perspectivas e intençóes filosóficas com que cada um, Schopenhauer e Bergson, abordam o problema do livrearbítrio, constatamos, quando consideramos alguns detalhes das explicaçóes que oferecem das açôes humanas, que elas coincidem em pontos importantes, e que a conclusão a que ambos, conjuntamente, chegaram não satisfaz nem aos adeptos do livre-arbítrio, nem aos deterministas. O caráter inesperado dessa coincidência, dada aquela oposição inicial entre as perspectivas filosóficas mais amplas de cada um desses filósofos, foi para nós um sinal de que estávamos aqui às voltas com um dado filosófico relativamente independente daquelas perspectivas, o qual é importante para o debate contemporâneo sobre o tema da liberdade das açóes humanas. É isso o que nos propomos mostrar no que segue.

\section{II - SCHOPENHAUER}

Schopenhauer caracteriza sua própria filosofia como um prolongamento da teoria de Kant a respeito da coexistência da liberdade com a necessidade, tal como resultante da solução da terceira das Antinomias kantianas da Razão Pura. Kant teria, nessa teoria, mostrado como nossas valoraçóes morais das açôes humanas são feitas independentemente do fato de que essas mesmíssimas ações, enquanto fenômenos temporalmente particularizados, são inteiramente explicadas como necessariamente resultantes de outras ocorrências anteriores, isto é, ele teria, segundo Schopenhauer, tornado compreensível como a liberdade inteligível, pressuposta por aquelas avaliaçóes, coexiste com a, mas não é afetada, diminuída ou anulada pela necessidade com que todas as açóes particulares resultam de condiçóes antecedentes. E, assevera Schopenhauer, o que a sua própria filosofia teria procurado fazer é estender esse resultado da filosofia kantiana, estender aquilo que essa teoria diz a respeito dos fenômenos humanos para todo tipo de fenômeno (WWV, I, 672; WWR, I, 501) - Mas não nos interessa discutir a "Metafísica da Natureza" que Schopenhauer acredita ser possível, através dessa extensão. Em outro lugar, cremos, poderia ser mostrado que tal "metafísica" foi equivocadamente pensada pelo próprio 
Schopenhauer como acalentando as mesmas pretensôes das metafísicas tradicionais, mas não podemos examinar esse ponto aqui. $\mathrm{O}$ que nos interessa notar, de início, é que Schopenhauer pretende, a respeito das ações humanas, estar aderindo completamente àquela teoria kantiana da coexistência da liberdade com a necessidade e, embora também não nos interesse discutir o quanto tal pretensão de Schopenhauer é legítima, ao menos um aspecto daquela teoria merece destaque: trata-se da diferenciação que Kant faz entre o caráter "inteligível" e o caráter "empírico" do homem (KANT, KrV, A-546s; B-574s]) - tal como todos os outros fenômenos, o homem tem, no que diz respeito ao seu caráter empírico, suas açóes inteiramente explicadas, e tornadas necessárias, por leis empíricas que as mostram como resultantes de outros fenômenos, ao passo que, quanto ao seu caráter inteligível, poder-se-ia, diante do outro tipo de necessidade com que o dever moral se lhe impóe, admitir um outro tipo de causalidade, uma causalidade mediante liberdade através da Razão. Não vamos, é claro, discutir os desenvolvimentos posteriores que Kant dá a esta ideia na Crítica da Razão Prática, nem vamos, também, examinar a radical rejeiçấo por parte de Schopenhauer, tal como formulada em seu Sobre o Fundamento da Moral, dessa fundamentação kantiana da moral. O que queremos notar especialmente em conexão com a teoria kantiana a respeito do caráter empírico do homem é que, segundo Kant, se pudéssemos investigar exaustivamente todas as manifestaçôes fenomenais da vontade do homem (alle Erscheinungensiener Willkür), "[...] não haveria ação humana alguma que não pudesse ser predita com certeza, e reconhecida como resultante necessário de suas condiçôes antecedentes." (KANT, KrV, A-550; B-578 [500]). Para Kant, o rigor com que aqui é afirmada a necessidade das manifestaçóes fenomenais do caráter é apenas um meio de tornar mais saliente aquilo que, segundo ele, escapa a essa necessidade, isto é, a liberdade implicada na ideia do dever moral; mas, conforme frisamos, não podemos aqui investigar até que ponto a antropologia, ou psicologia, científica poderia, segundo Kant, avançar. O que queremos notar é que é inspirado inicialmente nesse "determinismo das açóes particulares do homem", tal como admitido pela teoria kantiana da coexistência da liberdade com a necessidade, a respeito da qual Schopenhauer escreve seu Sobre a Liberdade da Vontade.

Segundo Schopenhauer, o conceito de liberdade é um conceito negativo, pois denota apenas a ausência de obstáculos (estes, sim, positivos) à ação, e originalmente diz respeito a uma liberdade meramente física, isto é, denota a ausência de obstáculos materiais (correntes, prisóes, doenças) à ação de um ser dotado de vontade, o qual agiria, então, apenas em conformidade 
com sua própria vontade. Contudo, salienta Schopenhauer, tal liberdade física, embora indiscutível, pois a experiência constantemente a confirma, concerne apenas à capacidade ou faculdade para agir, relaciona-se apenas ao fato de que, uma vez tendo a vontade desse ser chegado a querer fazer alguma coisa, esse ser, na ausência de obstáculos materiais, fará tal coisa. Tal ser, portanto, poderá corretamente dizer: "Eu posso fazer o que eu quiser; se eu quiser fazer isto, eu faço isto, e, caso houvesse eu querido fazer outra coisa, eu teria feito essa outra coisa - basta eu querer!" Mas, adverte Schopenhauer, a liberdade que interessa àqueles que defendem o livre-arbítrio não é essa liberdade meramente física, mas sim a chamada "liberdade moral", a liberdade que supóe que, mesmo na ausência de obstáculos materiais, um homem poderia, numa situação determinada, indiferentemente fazer isto ou aquilo, porque esse homem poderia, também indiferentemente, querer fazer isto ou aquilo. Ora, assinala Schopenhauer, essa última possibilidade, a liberdade ou indiferença do querer, é algo bem diferente e algo bem mais discutível do que a liberdade ou indiferença do agir, uma vez dada a resolução da vontade. Conforme ressalta Schopenhauer, na tese da "liberdade moral", a liberdade do agir é afirmada sob a pressuposição da, discutível, liberdade do querer: ela diz que a ação do corpo se seguirá à resolução da vontade, mas, sobre esta última, sobre o processo através do qual a vontade chega a querer alguma coisa, nada está decidido. Para que a tese do livre-arbítrio pudesse ser afirmada, seria preciso demonstrar que, nesse processo de resolução, a vontade mesma fosse livre, que ela, diante de motivos diversos e até opostos, pudesse indiferentemente querer um ou outro. Como Glock resumiu esse ponto, recomendando-o à consideração dos filósofos contemporâneos que se dedicam à ética: "Que eu tenha feito o que eu quis, isto só implicaria em que eu poderia ter agido diferentemente se eu pudesse ter querido agir diferentemente da maneira em que, de fato, agi." (GLOCK, 2009, p. 422). Os adeptos do livre-arbítrio equivocadamente têm, então, continua Schopenhauer, tomado a, indiscutível, "liberdade do agir, uma vez dada a resolução da vontade", como se ela estivesse estabelecendo de maneira igualmente indiscutível a "liberdade do querer", coisa que ela efetivamente não faz. $\mathrm{Na}$ verdade, sobre essa liberdade ou indiferença do querer, sobre a possibilidade de que a vontade, diante de um motivo, pudesse indiferentemente querê-lo ou não, ou, diante de motivos diferentes e opostos, pudesse indiferentemente querer um ou outro, enfatiza Schopenhauer, nada nos é dado. Ao contrário, sugere ele, seria bastante estranho alguém dizer que, embora presentemente queira uma coisa, poderia igual e indiferentemente estar, nesse mesmo instante, querendo outra coisa. Ou seja, se consultarmos 
nossa autoconsciência, conclui Schopenhauer, o máximo de informação que obteremos a respeito é a conclusão de que, a cada momento, nossa vontade quer apenas uma coisa, com exclusão de outras, e, se insistirmos no interrogatório, esta autoconsciência chegará rapidamente a um momento em que ela nada mais pode conceber claramente:

Em última análise, isso ocorre porque a vontade é o Eu real do ser humano, o verdadeiro núcleo de seu ser [...] Pois ele mesmo é da maneira em que quer, e quer da maneira em que é. Assim, perguntar-lhe se poderia querer diferentemente do que quer, é perguntar-lhe se poderia também ser uma pessoa diferente da que é: e isto ele não sabe. (LV, 50 , grifo nosso).

Com efeito, dirá Schopenhauer, nós só poderíamos, como pretendem os adeptos do livre-arbítrio, ter agido diferentemente do modo como de fato agimos se houvéssemos querido agir diferentemente, e nós só poderíamos ter querido agir diferentemente, se nossa vontade houvesse sido outra, se nosso caráter houvesse sido outro, se nós, enfim, fôssemos outra pessoa. Mas esta última possibilidade, além de, como frisa Schopenhauer acima, estar completamente fora daquilo que pode ser abarcado por nossa autoconsciência, contraria também, acrescentamos, os próprios dados iniciais em que o problema fora colocado, pois nele se trata da questáo sobre se esta pessoa poderia... etc.

Todavia, Schopenhauer não se limita a apontar o equívoco cometido pelos adeptos do livre-arbítrio - ele aponta também para a fonte da ilusão em que esses adeptos estão envolvidos e que os leva a cometer tal equívoco. $\mathrm{O}$ que leva tantas pessoas àquela confusão entre a liberdade para agir e a liberdade para querer, e à crença de que a liberdade nas açóes particulares é um fato indubitável? $\mathrm{Na}$ origem dessa "ilusão da liberdade empírica", salienta Schopenhauer, está uma compreensão equivocada do processo em que, em nós, a vontade passa de um mero desejo ou veleidade a um querer efetivo, a uma resolução, e à ação - durante todo o tempo imediatamente anterior ao instante em que se apresenta uma situação motivacional que exige efetivamente uma resolução de nossa vontade, nossa imaginaçấo apresenta os diversos e opostos motivos para que nossa vontade possa neles, por assim dizer, se exercitar, se experimentar; porém, nessa apresentação, cada motivo aparece isolado e separado dos outros, de modo que, quando da consideraçáo em separado de cada um desses motivos, a pessoa se acredita, a cada vez, como podendo querê-lo; e, após ter meramente imaginado ter querido igualmente a todos, ela, após a resoluçáo de sua vontade, imagina ou acredita erroneamente 
que um outro querer, diferente do querer real manifesto nessa resolução, houvera igualmente sido possível. Trata-se, conforme Schopenhauer, de uma confusão entre um mero desejo, ou entre um querer meramente imaginado e um querer efetivo, real, confusão esta propiciada pela posição subalterna ocupada pela autoconsciência, pelas faculdades intelectuais, conscientes e racionais, relativamente à vontade, pois

[...] é apenas a ação que adverte a auto-consciência de que um ato da vontade surgiu. Pois, em todo o período de tempo em que vai se elaborando, este (ato de início) se chama desejo, e, quando completo, se chama decisão; mas que ele tenha se completado (isto é, que a vontade tenha chegado a querer efetivamente alguma coisa), apenas a ação o demonstra à auto-consciência. E aqui encontramos a fonte principal daquela ilusão (de que), numa situação determinada, atos opostos da vontade seriam possíveis. (Tal ilusão) confunde o desejar com o querer. (A pessoa) pode desejar coisas opostas, mas só pode querer uma delas: e qual delas ela quer, isto só se revelará para sua autoconsciência através da ação. (LV, 46-47, grifo nosso).

Tal como mostrado no divertido exemplo do sujeito que, após concluir seu dia de trabalho, se imagina como podendo querer dar um passeio, ou querer visitar os amigos, ou querer ir a um clube noturno, ou querer subir uma torre para ver o pôr-do-sol, ou querer "cair no mundo" para não mais voltar, mas que, finalmente, se dá conta de seu querer real e efetivo de voltar para casa e para a esposa (LV, 68), o que ocasiona essa ilusão da "liberdade ou indiferença do querer" é o lugar subalterno ocupado pelas faculdades intelectuais, conscientes e racionais, relativamente à vontade, o que faz com que essas faculdades fiquem "por fora" e não participem efetivamente da decisão dessa vontade, e só possam ser informadas dessa decisão uma vez ela já concluída, e passada à ação. Diante de uma decisão a ser tomada, enfatiza Schopenhauer, essas faculdades intelectuais nada mais podem fazer do que apresentar à vontade os diversos motivos, a fim de que a vontade, como vimos, possa neles se exercitar, mas, sobre a decisão mesma, tais faculdades intelectuais precisam aguardar a açáo com a mesma curiosidade inquieta com que aguardaria a decisão proveniente da vontade de uma pessoa estranha (WWV, I, 400-1; WWR, I, 290-1). Tal como, por não controlar as condiçóes físicas precisas em que, por exemplo, uma moeda é lançada ao ar, nós dizemos que tanto pode resultar "cara" como pode resultar "coroa", assim também a autoconsciência, as faculdades intelectuais e racionais, de uma pessoa, por não controlar e não intervir efetivamente nas decisôes de sua vontade, confunde 
uma mera veleidade com um querer efetivo, e acredita erroneamente que, tendo querido realmente fazer uma coisa, poderia igual e indiferentemente ter querido fazer outra coisa.

Essa conclusão de Schopenhauer parece atingir realmente alguns aspectos da tese defendida pelos adeptos do livre-arbítrio, pois já não faz mais sentido dizer que uma pessoa, tendo querido fazer uma coisa, poderia igual e indiferentemente ter querido ter feito outra coisa. Mas, ao contrário do que pensa Schopenhauer, ela não é inteiramente conforme às expectativas dos adeptos do determinismo. Que a vontade, a cada momento, náo possa querer diferentemente do que ela efetivamente quer, isso, essa espécie de coerção da vontade, que a faz só querer o que efetivamente quer, se por um lado invalida algumas das pretensôes dos adeptos do livre-arbítrio, invalida também as pretensóes dos deterministas, já que estes gostariam de ver esse querer como determinado, ou tornado necessário, por alguma condição que lhe fosse antecedente. Ora, ao excluir as faculdades intelectuais da decisão da vontade, Schopenhauer náo se cansa de caracterizar essa vontade como absolutamente sem-fundamento, como sem-razão (grundlos). Por exemplo, no livro II de $O$ Mundo como Vontade e Representação, Schopenhauer, procurando determinar a essência íntima (innersten Wesen) da vontade humana que está prestes a ser estendida para a compreensão da essência íntima de todos os outros corpos, afirma:

Estes atos da vontade (Aktdes Willens) têm sempre um fundamento, fora deles, em seus motivos. No entanto, estes motivos determinam sempre apenas o que eu quero em tal momento, em tal lugar, em tal circunstância; mas não determinam que, em geral, eu queira, nem o que, em geral, eu quero, isto é, a máxima que caracteriza o todo de meu querer. Daí que $o$ meu querer, segundo sua essência integral, não pode ser explicado (erklären) pelos motivos [...] pois apenas os fenômenos da Vontade estáo submetidos ao Princípio da Razáo (Satz von Grund), mas não a Vontade mesma que, deste modo, deve ser designada como sem-Razão (ou sem fundamento grundlos). (WWV, I, 165-6; WWR, I, 106, grifo nosso).

É, de certa forma, espantoso que Schopenhauer não tenha, sobre esse ponto, se debruçado de uma maneira mais demorada sobre sua descoberta: ao longo de todo esse ensaio Sobre a liberdade da vontade, assim como na seção 55 do livro IV de sua obra-prima O Mundo como Vontade e Representação, ele, adotando a distinção kantiana, anteriormente mencionada, entre o caráter "inteligível” e o caráter "empírico", caráter empírico este que é apenas 
o desdobrar ou manifestar no tempo e na experiência do caráter inteligível e atemporal, pretende, contra os adeptos do livre-arbítrio, afirmar que toda ação é o resultado necessário da incidência de um motivo sobre um caráter empírico "determinado". Até esse ponto, Schopenhauer pretende estar, simplesmente, se adequando, e tornando mais precisa, a teoria kantiana da coexistência da liberdade com a necessidade. Contudo, quando se interroga Schopenhauer a respeito da medida em que esse caráter, mesmo o caráter "empírico", é determinado, muito de sua adesão ao determinismo cai por terra. Como esse caráter empírico é o mero desdobrar, sempre parcial, no tempo e na experiência a posteriori de um caráter inteligível atemporal, a priori e imutável, Schopenhauer teria que concluir, mas estranhamente não conclui, que esse caráter nunca é determinado da maneira exigida pelos deterministas - porque o caráter determinado da maneira desejada pelos deterministas é o caráter inteligivel, que é, assinala Schopenhauer, imutável, mas que também é apenas parcialmente e, por assim dizer, "pedaço após pedaço”, exibido na experiência e no tempo pelo caráter empírico. Ou seja, esse caráter inteligível, que é imutável e determinado da maneira exigida pelo determinismo, é incognoscível como tal! O caráter empírico, por outro lado, e enquanto tomado por si mesmo, nada tem de imutável e determinado e, no entanto, Schopenhauer constantemente transfere a imutabilidade, completude e determinação do caráter inteligível para o caráter empírico, e insinua sempre, de maneira equivocada, que esse caráter empírico tem seu querer necessariamente determinado pelo motivo que se apresenta e por aquilo que esse caráter, supostamente, já seria de forma completa. No entanto, esse caráter empírico nunca é, como Schopenhauer mesmo reconhece, uma revelação completa do caráter inteligível. Vê-se, assim, como o "determinismo dos motivos" de Schopenhauer depende de um confusão cometida por ele, e de que ele mal se dá conta. Aqui, a adesão de Schopenhauer às distinções kantianas parece encobrir, aos olhos do próprio Schopenhauer, aquela nãofundamentabilidade (Grundlosigkeit) irredutível da vontade, fazendo com que ele, tal como se vê na passagem acima (WWV, I, 165-6; WWR, I, 106), atribua essa não-fundamentabilidade apenas ao caráter inteligível, ao "querer em geral" do homem, e entenda o caráter empírico como "determinado" em cada um de seus atos de vontade particulares. $\mathrm{Na}$ verdade, porém, sua crítica ao caráter subalterno das faculdades intelectuais relativamente à decisão da vontade, que aponta para a não-fundamentabilidade (Grundlosigkeit) última desta, diz respeito não apenas ao caráter inteligível, à Vontade enquanto "coisa-em-si" do homem, mas também ao caráter empírico, concerne a cada 
querer particular ou manifestação fenomenal dessa Vontade. É por isso que, abordando esse caráter empírico, Schopenhauer o caracteriza de uma maneira que dificilmente poderia ser utilizada na defesa da tese determinista:

O caráter do ser humano é empírico. Apenas através da experiência podese ser informado a seu respeito, e isto, não apenas a respeito do caráter de outras pessoas, mas também a respeito de nosso próprio caráter [...] Portanto, diante de uma escolha difícil, nossa própria resolução, assim como a de outras pessoas, permanece um mistério para nós até que a escolha seja feita [...] Assim, ninguém pode, em última instância, saber como outra pessoa ou ela própria agirá numa determinada circunstância, até que ela mesma se encontre nesta circunstância; apenas através do feito, ou da ação realizada, ela pode estar segura a respeito das outras pessoas e, então, e só entáo, de $s i$ mesma também. (LV, 74, grifo nosso).

Ora, se o caráter empírico é o desdobrar ou manifestar no tempo e no fenômeno de um caráter inteligível atemporal, e se esse desdobrar ou manifestar é sempre parcial (o caso limite do momento final da morte da pessoa, momento em que haveria uma coincidência máxima entre o caráter inteligível e o caráter empírico, precisa ser excluído, já que, nesse caso, nenhuma escolha ou ação mais é de se esperar que ocorra), então, nem nós, nem a própria pessoa que o possui, poderia qualificar esse caráter como "determinado" seja de que maneira for! Essa imprevisibilidade absoluta do querer, essa Grundlosigkeit da vontade resultante do papel subalterno ocupado pelas faculdades intelectuais e racionais, faculdades que se ocupam, justamente, em fornecer "razóes" ou "fundamentos" segundo o Princípio de Razão Suficiente (Satz von Grund), não seria um sinal da liberdade ou indiferença do próprio querer da vontade, e, isso, não apenas da vontade "metafísica", ou do caráter inteligível, mas do próprio querer particular e fenomenal da vontade e do caráter empírico? E, no entanto, Schopenhauer está, ao longo de todo esse Sobre a Liberdade da Vontade, empenhado em negar essa liberdade ou indiferença do querer particular - adotando a teoria kantiana a respeito da "necessidade das açôes particulares", ele constantemente insinua que os motivos presentes numa situação "determinam" o querer particular da vontade, como se a vontade não pudesse, numa situação particular, resistir ao motivo que se lhe apresenta. Mesmo o exemplo do sujeito que, como vimos há pouco, ao sair do trabalho, imaginava-se como querendo fazer uma série de coisas diferentes, é mobilizado em função desse "determinismo dos motivos"; caso aquele sujeito descobrisse que ele, Schopenhauer, estivera atrás dele, anotando seus pensamentos, de modo a prever que o motivo "mais forte", o de 
voltar para a esposa, irresistivelmente venceria a disputa, esse sujeito poderia revogar sua decisão anterior e escolher fazer, ao invés, algumas daquelas outras coisas, mas mostra triunfante o "determinismo" de Schopenhauer, isso apenas porque um outro motivo, o de "contrariar o filósofo determinista", entrou em cena e se mostrou mais forte e determinante da vontade (LV, 69). Assim, na defesa desse pretenso "determinismo dos motivos", Schopenhauer salienta que, "[...] entre o chamado de seu dono e a visão de uma cadela, o cão hesita por alguns instantes; o motivo mais forte determinará seu movimento; mas entấo este movimento seguir-se-á de maneira tâo necessária quanto um efeito mecânico." (LV, 66). E, no mesmo espírito, acrescenta que todas as açóes executadas por uma pessoa são produtos necessários de seu caráter e dos motivos que se apresentaram, de modo que "[...] toda ação poderia ser prevista com certeza, poderia, de fato, ser calculada, não fosse o fato do caráter ser difícil de conhecer." (LV, 81, grifo do autor). Todavia, conforme vimos, o caráter náo é apenas difícil, como diz Schopenhauer aqui, de conhecer, mas, sim, impossivel - nem nós, nem a própria pessoa que o possui, conhece integralmente esse caráter inteligível, e aquilo que, desse caráter, foi dado a conhecer como manifesto no caráter empírico pode, no máximo, indicar uma tendência, mas não uma previsáo segura e calculada, como é a previsão de, para usar o exemplo de Kant do início deste texto, um eclipse solar. E, além disso, é claro que a "força" dos motivos em disputa, no caso do cão e do sujeito que terminava seu dia de trabalho, só pode ser aferida após a resolução e decisão da vontade - apenas após a decisão, uma decisão completamente infundada, ou grundlos, da vontade daquele sujeito, é que o "determinismo" de Schopenhauer irá qualificar um ou outro motivo como tendo sido o "mais forte". É por isso que, afinal, e como admitia o próprio Schopenhauer há pouco, nem nós, nem mesmo a pessoa pode prever como agirá numa determinada situação, porque o único conhecimento que permitiria tal tipo de previsão seria o conhecimento do caráter inteligivel, isto é, do caráter integral da pessoa - só esse tipo de conhecimento possibilitaria o estabelecimento de um verdadeiro determinismo dos motivos; mas é justamente o caráter inteligível que, segundo o próprio Schopenhauer, não pode ser conhecido, e isso não apenas por nós, mas também pela própria pessoa que o possui. Portanto, Schopenhauer não poderia, em que pese todo seu empenho equivocado em contrário, pretender estar se adequando e estabelecendo a tese determinista.

Vimos Schopenhauer recusar a tese dos adeptos do livre-arbítrio baseado na consideração de que, para que uma pessoa pudesse agir de uma maneira diferente daquela com a qual, de fato, agiu, seria preciso que ela 
houvesse querido agir diferentemente, isto é, seria preciso que ela houvesse possuído uma outra vontade, um outro caráter, que ela, enfim, houvesse sido outra pessoa. E, com efeito, Schopenhauer constantemente afirma que, embora as açôes de uma pessoa sejam o resultado necessário da incidência de motivos sobre seu caráter, esse caráter mesmo bem poderia ser outro, isto é, não há razão ou fundamento algum para que a pessoa seja a pessoa que é, para que possua o caráter ou a vontade que possui, ao invés de possuir outro caráter e vontade, ao invés de ser outra pessoa. É por isso que, como exemplifica magistralmente Schopenhauer, no remorso ou dor de consciência moral, o que se lamenta não é a efetivação da ação como tal (pois o indivíduo sabe que, sendo quem ele é, e estando naquela situação, aquilo que foi feito precisava ser feito, ou náo podia deixar de ser feito), mas sim o aspecto do caráter tornado manifesto por aquela ação - o que a pessoa lamenta é ser quem é, querer da maneira que quer, e a ação só é condenada na medida em que patenteia e torna manifesta essa maneira de ser e de querer. É nessa nãofundamentabilidade (Grundlosigkeit) da vontade ou do caráter da pessoa que Schopenhauer vê o único sentido aceitável de "liberdade", de uma liberdade que, enquanto mera ausência de razões necessitantes, está efetivamente na base dos fenômenos morais. Contudo, imediatamente após descobri-la, ele comete a seu respeito dois equívocos - primeiro, exagerando na separação kantiana entre os domínios fenomênico e inteligível, ele empurra tal liberdade para o domínio metafísico da Vontade "em si" e do caráter inteligível, ao mesmo tempo em que, insistindo na defesa da tese da necessidade das açóes enquanto fenômenos, ele não a reconhece no querer particular - de sorte que os motivos passam a ser vistos por ele como "determinando" de maneira irresistível a vontade, passam quase a figurar como "causas, razóes ou fundamentos" do querer particular da vontade. E, no entanto, é ele mesmo quem reconhece que nenhum motivo, nem mesmo aquele que costumeiramente é considerado como sendo o mais "forte", a saber, o da "preservação da vida própria", tem poder absoluto sobre a vontade, já que ele é recusado nas experiências do suicídio e do sacrifício pelos outros (LV, 37). É verdade que ele reconhece, nos fenômenos morais em que a vontade se nega a si mesma, uma irrupção dessa liberdade, ou não-fundamentabilidade, da vontade no próprio domínio dos fenômenos (WWV, I, 397; WWR, I, 288), porém, isso faz dessa irrupção algo especial e raro, e o faz deixar de notar que essa liberdade, essa Grundlosigkeit, da vontade a acompanha em cada querer, por mais insignificante e particular que seja - porque, se não há razão pela qual uma pessoa seja quem é, e se não há razão ou fundamento pela qual ela possua a vontade que possui, então 
também não há razão ou fundamento, seja para aquilo que essa pessoa quer em geral, seja para aquilo que ela quer em particular. Como pôde Schopenhauer não extrair essa consequência, evidente, de sua teoria e, ao contrário, ter insistido na tese de que o caráter de uma pessoa está, em cada situação, "determinado" de uma maneira ou outra, ou "determinado" pelos motivos que se apresentam?

Um segundo equívoco acerca dessa liberdade se acrescenta a este: vimos que essa liberdade e Grundlosigkeit da vontade eram imediatamente afirmadas a partir da constatação do papel subalterno das faculdades intelectuais, conscientes e racionais, relativamente à decisão da vontade, faculdades intelectuais que, com efeito, se dedicam à tarefa de fornecer "razôes ou fundamentos", em particular, razóes e fundamentos para a escolha e decisão sobre um curso de ação a ser seguido. Ora, após constatar que essa ponderação racional (vernünftige Überlegung) não interfere nas decisóes da vontade, Schopenhauer deixa de notar que o que essa ponderação racional procura excluir é justamente a liberdade de indiferença, é o "querer por querer", é o querer sem-razão ou sem-fundamento - ele chega, ao contrário, a inexplicavelmente atrelar a afirmação da liberdade de indiferença à concepção intelectualista, a qual vê na capacidade ou faculdade de fornecer "razóes" a essência do homem:

A defesa da (tese) da liberdade empírica da vontade, do liberum arbitrium indifferentiae, está estreitamente conectada à concepção que coloca a essência do homem numa alma que é originalmente um ser que conhece, de fato, um ser que pensa abstratamente, e apenas em consequência disto, um ser que quer. (WWV, I, 403; WWR, I, 292).

Como pode Schopenhauer afirmar isso, quando se considera que a ponderaçáo racional procura, justamente, excluir a liberdade de indiferença? Constatamos, assim, que Schopenhauer, após ter, de maneira muito bemsucedida, descoberto a Grundlosigkeit da vontade, Grundlosigkeit que é idêntica à liberdade de indiferença, em consequência de sua crítica revolucionária sobre o papel subalterno das faculdades intelectuais relativamente à decisão da vontade, adota em relação a essa Grundlosigkeit procedimentos bastante questionáveis - por um lado, ela é empurrada para o domínio quase inacessível das coisas em si mesmas, deixando suas manifestaçóes particulares como quase "mecanicamente determinadas", e, por outro lado, seu vínculo evidente com a liberdade de indiferença é desconsiderado, liberdade esta que, estranhamente, 
é vinculada por Schopenhauer à concepção intelectualista que foi, justamente, desqualificada por sua crítica.

Enfim, se, contra os adeptos do livre-arbítrio, Schopenhauer tem razão ao afirmar que a vontade, uma vez tendo chegado a querer fazer uma coisa, não poderia ter querido fazer outra coisa, contra os adeptos do determinismo, ele deveria ter reconhecido, claramente, que a vontade, quando quer uma coisa, ou quando quer fazer uma coisa, ela o quer de uma maneira completamente infundada, sem-razão, sem nenhuma condição antecedente em relação à qual esse querer poderia ser encarado como necessário. E, isso, tanto no que diz respeito à Vontade metafísica, geral ou "em-si", como também no que concerne a cada manifestação particular e fenomênica dessa vontade. Schopenhauer, no entanto, equivocadamente empurrou essa (evidente) liberdade de indiferença ou Grundlosigkeit da vontade para o domínio inacessível, porque nunca inteiramente revelado pela experiência, do caráter inteligível, ao mesmo tempo em que inadvertidamente atribuiu ao caráter empírico a mesma inalterabilidade e completude que são supostamente características do caráter inteligível, aderindo, assim, também equivocadamente, a um "determinismo" que sua descoberta original, na realidade, não suporta, mas contraria.

\section{BERGSON}

Embora Bergson esteja empenhado, em sua primeira obra filosófica significativa, o Essai sur les données de la conscience, de 1888, em demonstrar que, tanto deterministas como adeptos do livre-arbítrio compartilham uma mesma pressuposição equivocada, a saber, a transposição ou tradução da temporalidade da vida consciente, em termos espaciais, sua principal intenção nessa obra é, no entanto, contrapor-se às tendências deterministas prevalecentes, tais como o "determinismo dos motivos" defendida há pouco por Schopenhauer, na ciência, principalmente na psicofisiologia e na psicologia associacionista de sua época. Para isso, ele analisa, de forma bastante minuciosa e sofisticada, alguns conceitos mobilizados por tais ciências, como os conceitos de "quantidade intensiva" e de "estados psicológicos", com o objetivo de mostrar que tais conceitos, ao invés de refletirem e captarem a temporalidade verdadeira da vida da consciência, na realidade, são construídos sobre a intuição de um espaço homogêneo, de um espaço no qual aquilo que é característico e essencial a essa vida não pode se acomodar. A partir dessa análise Bergson procurará chegar a conclusóes inovadoras a respeito do problema da liberdade, conclusóes 
que, como veremos, estarão muito próximas àquelas que Schopenhauer teria chegado, não fosse, como vimos, sua equivocada defesa de um "determinismo dos motivos". Para que possamos apreciar o valor dessas conclusóes de Bergson a propósito da liberdade, precisamos, no entanto, examinar primeiro a sua análise daqueles conceitos através dos quais o determinismo que ele combate pretendia se afirmar.

Começando com o conceito de "quantidade intensiva" da psicofisiologia, Bergson pergunta: o que queremos dizer, quando afirmamos que uma sensação, por exemplo, é "maior", ou mais "forte", que outra? Obviamente, continua ele, o que pretendemos significar com isso não pode ser o mesmo que significamos, quando dizemos que um número, ou uma parte do espaço, é maior que o outro, pois aquilo que torna possível esta última relação é uma relação prévia de um continente para com os seus conteúdos, relação esta que não existe entre sensaçôes. As sensaçôes não podem ser justapostas ou sobrepostas umas às outras. Uma verdadeira mensuração ou medida aqui é impossível, porque, nesse domínio, a igualdade qualitativa implica identidade - uma sensação não pode ser dita igual a outra, a não ser que se trate da mesma sensação (e, nesse caso, não se trataria de duas sensações). Na construção de um número, prossegue Bergson, precisamos supor elementos qualitativamente iguais e, no entanto, ainda discerníveis como não sendo os mesmos, como diferindo ainda uns dos outros de algum modo. É, portanto, assinala Bergson, o nivelamento ou a abstração do aspecto qualitativo e a intuição do espaço o que tornam possíveis o número e a medida - dois elementos, qualitativamente iguais, só podem ser ditos não serem o mesmo elemento se estiverem posicionados em duas regióes diferentes do espaço. Porém, constata Bergson, no caso das sensaçóes, não existem tais relaçóes espaciais, e o aspecto qualitativo, o qual deveria ter sido nivelado ou abstraído para que a própria atividade de mensuração fosse possível, é justamente aquilo que a psicologia psicofisiológica pretende medir. Trata-se, por conseguinte, conclui Bergson, de uma tarefa impossível. Evidentemente, na linguagem cotidiana, consideramos um sentimento ou sensaçáo como "maior" ou mais "forte" que outro, mas é óbvio que, com tais expressôes, não pretendemos significar nenhuma mensuração efetiva. Assim, conclui Bergson, quando o psicofisiologista tenta mensurar sensações, ele está indevidamente pressupondo uma tradução ou transposição da temporalidade consciente, em termos espaciais, e, na medida em que nessa transposição aquela vida perde suas características essenciais, ele não está mensurando efetivamente nada. 
Tais características da temporalidade da vida consciente são mais claramente percebidas a partir da análise que Bergson promove do conceito de "estados psicológicos", tal como admitido pela psicologia associacionista. O que o psicólogo associacionista pretende dizer, quando alude a uma multiplicidade de tais estados? Tratar-se-ia, continua a perguntar Bergson, de uma multiplicidade numérica? Para que o adicionar e o contar sejam possíveis, é preciso a intuição de um medium no qual, à medida em que passamos de um elemento a outro, o primeiro elemento, que agora já é passado, seja ainda preservado e retido, de modo a ser justaposto ao novo elemento que agora está sendo considerado. E o medium no qual isso é possível é, frisa Bergson, o espaço, porque um momento do tempo, por sua própria natureza, não pode permanecer, de sorte a ser acrescentado a outro momento. Contudo, mais que isso: de maneira a que sejam possíveis a adição e a contagem é necessário, não só que os elementos passados sejam preservados, mas também que sejam preservados como elementos distintos ou discerníveis do elemento presentemente sob consideração. Eis aqui o que Bergson chama de "exterioridade recíproca”, e que é, segundo ele, uma característica essencial da nossa intuição de um espaço homogêneo e da nossa intuição dos estados do mundo, material ou físico, externo - essa característica consiste em que, onde se encontra uma parte do espaço, a outra parte não se encontra ou, quando um estado do mundo aparece, o outro estado anterior já desapareceu completamente. Essa característica da "exterioridade recíproca", assim como a característica anterior, a qual poderíamos chamar de "discernibilidade nãoqualitativa”, da nossa intuição de um espaço homogêneo é o que torna possível tanto a mensuração, a adição e a contagem quanto, destaca Bergson, e isso é especialmente importante para a o problema da liberdade, a previsibilidade - pois são essas características da intuição do espaço homogêneo aquilo que, ultimamente, torna possível que um estado do mundo externo possa ocorrer novamente da mesma maneira como ocorrera anteriormente. $\mathrm{Na}$ intuição do mundo externo, conforme Bergson, temos apenas simultaneidades, temos apenas o presente. Não há aí nem duração nem sucessão, já que estas existem apenas para uma consciência, na qual o passado pode coexistir com o presente. No mundo externo mesmo, ocorrem mudanças, mas mudanças que não redundam em sucessão, já que o novo estado exclui completamente, é “reciprocamente exterior" em relação ao estado anterior. Esses estados podem, assim, ocorrer novamente, eles são reprodutíveis, porque, tendo já em sua primeira ocorrência sido completamente distintos e indiferentes aos outros estados coexistentes e anteriores, são suscetíveis de acontecerem novamente 
em meio a estados que são completamente diferentes dos estados anteriores. Toda a previsibilidade, toda a capacidade preditiva da ciência, assinala Bergson, repousa sobre aquelas características, a "discernibilidade quantitativa" e a "exterioridade recíproca”, da intuiçâo do espaço homogêneo, que faz com que um estado possa ser preservado, e preservado como quantitativamente distinto de outros estados coexistentes e anteriores, e que possa aparecer, e reaparecer tal qual, mesmo que circundado por outros estados muito diferentes dos anteriores.

No entanto, continua Bergson, com o conceito de "estado psicológico", o psicólogo associacionista pretende estar capturando os momentos da nossa vida consciente e psicológica, da mesma maneira como o conceito de estado físico ou material captura os estados do mundo externo, isto é, ele concebe os momentos daquela vida da consciência como se estes fossem "reciprocamente exteriores" uns aos outros - esse psicólogo pretende dizer que, por exemplo, quando alguém alega ter a "mesma" dor que teve dias ou anos atrás, se trataria da recorrência de um mesmo estado em meio a circunstâncias psicológicas circundantes completamente diferentes. Bergson reconhece que, com propósitos práticos (por exemplo, quando se trata de comunicar nossos sentimentos e, nesse caso em especial, quando se trata de pedir ajuda), estamos autorizados a fazer abstração das diferenças entre as circunstâncias psicológicas circundantes, circunstâncias que fazem com que a dor atual seja tão diferente da, e quase incomensurável com, a dor anterior - e é com estes mesmos propósitos práticos que nós simbolizamos esses sentimentos artificialmente "solidificados" mediante uma única palavra - "dor". As palavras de nossa linguagem, para Bergson, com seus significados precisos, estáveis, nitidamente definidos, impóem aos sentimentos e sensaçóes que, por razóes práticas, eles denotam a mesma "exterioridade recíproca" que, de fato, não existe na temporalidade pura da vida consciente:

Eu me levanto para abrir a janela mas, uma vez em pé, eu me esqueço do que pretendia fazer; permaneço em pé, parado - Isto é fácil de explicar, diz o psicólogo associacionista: você associou duas idéias; uma, a do objetivo a atingir, a outra, a do movimento a executar; uma dessas idéias desapareceu, e restou apenas a idéia do movimento - Entretanto, eu não volto a me sentar. Obscuramente sinto que tenho ainda uma coisa a fazer. A minha imobilidade não é uma imobilidade indiferenciada; na posição em que parei está, por assim dizer, pré-figurado o que eu pretendia fazer; assim, tudo o que preciso fazer é manter esta posição [...], senti-la de modo atento, para encontrar nela a idéia que foi esquecida momentos atrás. (BERGSON, 1967, p. 140). 
Na temporalidade pura da consciência, ressalta Bergson, os momentos que se sucedem penetram-se mutuamente, de maneira que, quando o momento novo e presente surge, ele já era como que pré-figurado e anunciado pelos momentos anteriores; e nós encontramos, nesse momento novo e presente, vestígios dos momentos que acabaram de passar. Bergson diria, antecipando algumas das consideraçóes que serão feitas por Husserl, a propósito da consciência íntima do tempo, nos cursos de Götingen de 1905, que um momento presente e atual da duração pura nunca é apenas "presente", mas é sobrecarregado com vestígios do recém-passado e anúncios do futuro prestes a surgir. E, continua ele, quando um novo momento dessa duração surge, ele não é meramente adicionado aos momentos anteriores, mas, ao contrário, ele se integra e se organiza com eles, constituindo um complexo de elementos completamente novo. É como, compara Bergson, a nota atual de uma melodia, nota que, quando aparece, já era pré-figurada e anunciada pelo complexo das notas anteriores, e que, ao surgir, rearranja ou reorganiza esse complexo, constituindo com as outras notas um complexo novo, ao mesmo tempo em que já anuncia ou pré-figura a nota que está prestes a surgir. Nossa vida consciente ou psicológica é, de acordo com Bergson, como uma melodia: cada momento dessa vida tem sua inserção num complexo específico e irreprodutível de circunstâncias psicológicas circundantes, e não pode dessas circunstâncias ser separado sem que, concomitantemente, perca sua própria identidade. Nenhum momento desse complexo orgânico continua a ser o mesmo momento, quando dele artificialmente separado e artificialmente inserido num outro complexo.

Tendo, assim, caracterizado a duração pura de nossa vida consciente, Bergson pode agora, não exatamente resolver, mas sim dissolver o problema em torno do qual se opóem deterministas e adeptos do livre-arbítrio: esse problema, enfatiza Bergson, tal como formulado por ambos os oponentes, não pode ser resolvido, e deve ser considerado como sem-sentido - não faz sentido perguntar se, dadas as mesmas condiçóes, uma pessoa pode (como afirmam os adeptos do livre-arbítrio) ou não pode (como afirmam os deterministas) fazer algo diferente do que anteriormente fez, porque nós não podemos considerar a nossa vida psicológica ou consciente como se, nela, fosse possível "dar-se as mesmas condiçôes". Como vimos, nessa vida está excluída a possibilidade da repetição ou recorrência de seus momentos, de modo que ambos os oponentes, deterministas e adeptos do livre-arbítrio, formulam sua oposição sob um pressuposto comum, sob um pressuposto que, pura e simplesmente, é falso. Por exemplo, quando se trata da questão sobre a 
"decisão deliberada", ambos os oponentes, aceitando de forma não-crítica as "solidificaçôes" artificiais introduzidas na vida psicológica pela linguagem de utilidade prática, concebem a pessoa que está deliberando como se ela estivesse oscilando, como um pêndulo, entre duas direçóes artificialmente solidificadas, por exemplo, as direçóes (A) e (B). Contudo, frisa Bergson, o que realmente ocorre é que essa pessoa, após considerar sucessivamente as direções (A) e (B), irá, quando voltar a reconsiderar a direção $(\mathrm{A})$, encontrar-se numa situação diferente daquela em que se encontrava quando, pela primeira vez, considerou a direção (A). Já não se trata da mesma direção (A), pois, no entretempo, a pessoa adquiriu a experiência da consideração da direção (B). Assim, conclui Bergson, quando se levam em conta as características da temporalidade pura da vida consciente, que exclui a possibilidade de uma "exterioridade recíproca" e de uma "reprodutibilidade" de seus momentos, a posição do determinista se vê reduzida à afirmação, banal, de que o desenrolar dessa vida até esse momento foi esse, de que o que foi feito até agora, foi feito, ao passo que a posição do adepto do livre-arbítrio se vê reduzida à afirmação, igualmente banal, de que o desenrolar dessa vida, que ainda não foi feito, não foi feito.

Essa conclusão de Bergson parece atingir, efetivamente, algumas das pretensóes dos deterministas e, embora Bergson pretenda que ela seja igualmente desfavorável às pretensóes dos adeptos do livre-arbítrio, todo o seu empenho nesse Essai é direcionado ao aprimoramento do argumento desses últimos, isto é, à defesa da tese da liberdade. E é justamente nessa defesa da tese da liberdade que encontraremos Bergson como se aproximando, inesperadamente, do "determinista" Schopenhauer. Se, conforme vimos, a defesa que Schopenhauer promove da tese do "determinismo dos motivos" é equivocada, a ponto de contrariar as pretensóes deterministas, veremos que a defesa da tese da liberdade que Bergson promove tampouco satisfaz aos adeptos do livre-arbítrio. Será nesse ponto, conforme anunciamos no início deste texto que encontraremos ambos os filósofos apreendendo as açóes humanas de uma maneira que não se adequa às concepçóes, nem deterministas, nem libertistas, e que aponta para um ganho efetivo na solução do problema da liberdade. Continuemos acompanhando a análise de Bergson.

Quanto à previsibilidade das ações humanas, Bergson, como vimos, nega que ela seja possível. Ele chega mesmo a forjar a imagem, que lembra o exemplo anterior dado por Schopenhauer, de um filósofo, chamado Paulo, que está tentando predizer o resultado da deliberação que está em curso na cabeça de outra pessoa, chamada Pedro. Paulo, frisa Bergson, pode tentar basear sua predição nas representaçôes simbólicas que Pedro tem de seus próprios estados 
psicológicos prévios, mas, nesse caso, a intensidade peculiar a cada estado, passível de influenciar na decisão, só poderia ser avaliada após a decisão ser concluída, e a ação realizada - visto que os termos utilizados por Pedro, no relato das experiências pelas quais passou, denotariam sentimentos e sensaçóes artificialmente solidificados e anônimos, os quais não permitiriam apreciar sua importância no processo decisório. Todavia, Paulo pode, continua Bergson, tentar uma outra via: tal como um escritor, num romance ou num drama, pode, mediante o delineamento preciso do caráter dos personagens e das situaçóes em que se encontram, chegar a representar sentimentos e pensamentos de uma maneira mais concreta do que as representaçóes simbólicas da linguagem o fazem, levando o leitor a assumir, simpaticamente, os sentimentos e pensamentos do personagem como se fossem seus próprios sentimentos e pensamentos, assim também o filósofo Paulo poderia tentar coincidir simpaticamente com a pessoa de Pedro de um modo tal, que toda experiência ou vivência de Pedro, por menos importante que fosse, fosse igualmente experimentada ou vivida por ele. Mas, para que a previsão pretendida por Paulo fosse possível, seria preciso que essa coincidência simpática se estendesse tanto a tudo aquilo que já foi vivido por Pedro quanto ao momento presente em que Pedro está deliberando. Assim, assevera Bergson, nesse momento, constatamos que tudo o que o filósofo Paulo poderia predizer a respeito da deliberação de Pedro é o que o próprio Pedro poderia predizer a respeito de sua própria deliberação. E, conclui Bergson de uma forma muito semelhante àquela como concluía Schopenhauer, há pouco, tudo o que o próprio Pedro pode saber a respeito do processo de deliberação que está em curso, em sua própria mente, ele o sabe apenas quando essa deliberação está prestes a ser concluída, e está em vias de se manifestar como uma ação efetiva:

Eis uma questão sem-sentido: a ação poderia ou não poderia ser prevista, uma vez dada a totalidade de suas condiçóes antecedentes? [...] Quando, através de transiçóes graduais, coincidimos com a pessoa (cuja ação estamos tentando prever), quando passamos pela mesma série de estados, e quando, assim, nos aproximamos do exato instante no qual a ação está se realizando, então já não se trata de prevê-la [...] Nós apenas vivenciamos esta duração na medida em que ela se desenrola. Em resumo, no domínio dos fatos psicológicos profundos, não há diferença notável entre prever, ver, e agir. (BERGSON, 1967, p. 108).

Tal como constatava o "determinista" Schopenhauer, tudo o que nós podemos saber, e tudo o que a própria pessoa, cuja ação estamos tentando 
prever, pode saber a respeito da decisão que está tomando, é conhecido, afirma também Bergson, apenas no momento em que essa decisão está sendo tomada, ou já foi mesmo concluída. No caso de decisôes importantes, de decisóes que representam, como se diz, encruzilhadas vitais, o nosso Eu "profundo", completa Bergson, pode irromper no, e romper os automatismos do, Eu "superficial" - já não se trata da, mais ou menos previsível e automática, escolha de, por exemplo, uma ou outra marca de refrigerante, mas sim de uma alternativa entre açóes que mudaráo todo o curso futuro da vida da pessoa. Nesses casos importantes, assinala Bergson (1967, p. 111):

Quando escrupulosamente investigamos dentro de nós mesmos, vemos que acontece de pesarmos razóes, deliberarmos, ao mesmo tempo em que a decisão parece já ter sido tomada [...] A intervenção repentina da vontade é como um golpe de estado de que nossa consciência tinha um pressentimento, e que ela procura antecipadamente justificar através de uma legislação oficial. É verdade que podemos perguntar se a vontade, quando ela quer porque quer, não estaria ainda obedecendo a alguma razão decisiva, ou se o "querer por querer" é realmente um querer livre.

Nessas passagens de tom inequivocamente schopenhaueriano, Bergson está afirmando a mesma cognoscibilidade meramente empírica ou a posteriori das decisóes da vontade por parte das faculdades conscientes e racionais que, há pouco, era afirmada por Schopenhauer. Até mesmo o caráter subalterno dessas faculdades, as quais se limitam a justificar post factum a decisão semfundamento e sem-razão da vontade, é admitido por ele. E a questão levantada por último, se o "querer por querer", isto é, o querer sem razão, é realmente um querer livre, será, surpreendentemente, respondida afirmativamente por Bergson (1967, p. 118-119):

Quando nossos amigos mais confiáveis concordam em nos recomendar algo sobre uma decisão importante, seus conselhos são depositados na superfície de nosso $\mathrm{Eu}[. .$.$] Acreditamos ter agido livremente, e apenas depois, quando$ refletimos sobre o que ocorreu, é que reconhecemos nosso erro. Mas, no momento em que a ação está prestes a efetuar-se, não é incomum ocorrer de uma revolta irromper [...] É nosso Eu profundo que vem à superfície [...] Eis porque procuramos em vão explicar nossa repentina mudança na decisão mediante apelo às circunstâncias que aparentemente a precederam [...] Queremos saber a razão pela qual decidimos, e constatamos que decidimos sem nenhuma razão e, talvez, contra toda a razão. (Grifo nosso). 
São nesses momentos importantes de nossa vida, nos quais nosso $\mathrm{Eu}$ mais fundamental, nossa personalidade integral, irrompe em nosso Eu superficial, rompendo-lhe os sentimentos e opinióes artificialmente solidificados, anônimos e simbólicos, frisa Bergson, que podemos nos apreender como verdadeiramente livres. Mas, se assim é, como não qualificar essa liberdade como uma liberdade de indiferença? Como não identificála à Grundlosigkeit da vontade, que, apesar da equivocada ênfase num suposto "determinismo dos motivos", era destaque na análise promovida por Schopenhauer? Schopenhauer não fazia uma clara distinção entre decisôes "importantes" e "triviais", e Bergson não distingue entre um caráter "inteligível" e um caráter "empírico", entretanto, no fundo, ambas as análises coincidem na afirmaçáo dessa liberdade da vontade como ausência de razóes ou fundamentos necessitantes de cada uma das manifestaçôes de seu querer. Mas, tal como antes constatamos que os resultados obtidos pela análise de Schopenhauer não se adequava inteiramente, ao contrário do que ele próprio pensava, às expectativas dos deterministas, agora vamos verificar que essa análise de Bergson, ao contrário também do que ele próprio acredita, não satisfaz às expectativas dos adeptos do livre-arbítrio.

Arnaud François, em seu "La volonté chez Bergson et Schopenhauer", procurando apontar para uma convergência entre as "ontologias da vontade" de Bergson e de Schopenhauer, começa por ressaltar as divergências de ambos sobre outros pontos, incluindo uma suposta divergência sobre o ponto que nos ocupa aqui - referindo-se especificamente ao Essai, François sustenta que, a respeito da liberdade, Bergson ultrapassa Schopenhauer, na medida em que ele não aceita a oposição, admitida por Schopenhauer, entre a liberdade de indiferença e o determinismo (FRANÇOIS, 2004, p. 5). Mas, conforme vimos, o "determinismo" de Schopenhauer é mais aparente do que real, e a liberdade que Bergson pretende afirmar é, como acabamos de ver, muito próxima da liberdade de indiferença. De qualquer forma, François, mesmo pretendendo salientar uma suposta divergência entre ambos os filósofos, a respeito do tema da liberdade das açóes humanas, pergunta-se sobre uma inesperada convergência entre ambos:

Agora, encontramos em Bergson e, mais particularmente, em seu Essai sur les données immédiates de la conscience, que diz respeito ao problema da liberdade, vestígios da concepção de um "querer por querer", de uma

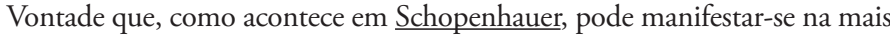
completa ausência de motivos (abstratos)? [...] De fato, imediatamente após a publicação do Essai de Bergson, foi levantada [...] a objeção de que Bergson 
estaria afundando a Razão numa espécie de fluxo indistinto de consciência, isto é, numa mera espontaneidade que mal e mal é consciente de si mesma [...] (FRANÇOIS, 2004, p. 10).

Recusando essa objeção, François procurará mostrar que, em Matière et Mémoire, Bergson desfaz essa impressão, e qualifica toda duração humana como intrinsecamente razoável. Entretanto, não precisamos acompanhar Bergson nesse aspecto, nem procuraremos contestar a opiniáo de François a respeito. Em seu Essai, ao menos, Bergson entende a "Razão", juntamente com a linguagem e a inteligência prática, como pertinente ao Eu "superficial", ao Eu público que, por lidar com a espacialidade homogênea do mundo externo, adquire desse contato a "exterioridade recíproca" característica de seus estados. As açóes e decisōes triviais e comuns desse Eu superficial não são, assevera Bergson, livres, mas sim determinadas e em grande parte previsíveis, tal como são previsíveis e determinadas as suas contrapartidas do mundo externo. As açôes do Eu que realmente são livres, de acordo com Bergson, são aquelas em que os sentimentos e pensamentos desse Eu superficial são rompidos pela irrupçáo do Eu profundo, do Eu que, como acabamos de ver no relato de Bergson, "quer porque quer", isto é, quer sem nenhuma razão ou fundamento. Assim, podemos notar que, ao contrário do que François pretende mostrar, ao menos no Essai, Bergson entende a "razão" e o "razoável” como estando no Eu, o qual, justamente, não é livre.

Todavia, essa inesperada convergência entre Schopenhauer e Bergson nos dá a oportunidade, enfim, de perguntar se, e em que medida, a concepção bergsoniana de liberdade satisfaz às expectativas dos adeptos do livre-arbítrio. Se, conforme vimos, a questáo da previsibilidade era o calcanhar de Aquiles do suposto "determinismo" de Schopenhauer, a questão da escolha parece ser o calcanhar de Aquiles da liberdade bergsoniana. Com efeito, dirá o adepto da tese do livre-arbítrio, é essencial ao conceito de "ação livre" que essa ação seja uma ação escolhida. $\mathrm{O}$ conceito negativo de liberdade, como independência relativamente a toda necessidade, e o conceito de liberdade de indiferença, como independência em relação a qualquer razão ou fundamento, não podem satisfazer às exigências daquilo que é pensado sob o conceito de liberdade, já que este implica liberdade de escolha. Nós não podemos, continua esse adepto do livre-arbítrio, conceber a liberdade a náo ser como liberdade de escolha, e não podemos também conceber uma escolha a não ser como resultante de um processo de deliberação no qual se avaliam e se pesam ao menos dois 
motivos ou alternativas diferentes. Mesmo admitindo, continua esse adepto, a interpenetração recíproca dos momentos da consciência, tal como estudados por Bergson, é preciso, para que uma escolha seja possível, que haja entre essas duas alternativas uma certa "exterioridade recíproca". Mas isso, exclama esse adepto, é justamente o que Bergson nega! Se, continua ele, na resolução de um conflito ocorre, tal como propóe a análise bergsoniana, uma espécie de mistura, fusão e amálgama entre as alternativas conflitantes, como dizer que uma escolha foi feita, pois "escolher algo" significa "preterir ou abdicar de outro algo"? Mas Bergson, conclui esse adepto do livre-arbítrio, ao negar a possibilidade de uma "exterioridade recíproca" entre essas alternativas conflitantes, entre a coisa escolhida e a coisa preterida, está negando, sem dar-se conta disso, também a própria possibilidade de uma escolha e, consequentemente, está negando a própria possibilidade da liberdade.

\section{IV - ConClusão}

Vimos que Schopenhauer estava correto ao sustentar, contra as pretensões dos adeptos do livre-arbítrio, que, tendo a vontade chegado a querer fazer uma coisa, não faz sentido dizer que ela poderia ter igualmente querido fazer outra coisa. Essa ação deve ser reconhecida como necessária, mas, isso, apenas no sentido de que náo poderia ter sido outra. Entretanto, Schopenhauer, por entender que a necessidade inclui principalmente a característica de "seguir-se a uma razão suficiente", acaba indevidamente atribuindo à vontade empírica a mesma determinação incognoscível da vontade inteligível, e passa a encarar os motivos como razâo ou fundamento de cada querer particular da vontade, obscurecendo sua própria descoberta a respeito do caráter absolutamente semrazão (grundlos) e livre daquele processo através do qual a vontade chega a querer fazer alguma coisa. E Bergson tem razão contra o determinista, quando salienta o caráter orgânico da temporalidade da vida da consciência, de uma organicidade que, no limite, inviabiliza a aplicação do próprio princípio de causalidade aos momentos da consciência - pois "causa" e "efeito" precisam ser definidos independentemente um do outro, isto é, é preciso que ambos sejam reciprocamente exteriores um ao outro, algo que, como apontou Bergson, é impossível na temporalidade da vida da consciência. Da mesma maneira, sua demonstração a respeito do caráter único e irrepetível de cada um dos momentos dessa consciência é um duro golpe para as pretensóes deterministas. Mas, se, como pretende Bergson, cada momento da consciência é absolutamente novo, como acomodar a ideia de uma liberdade de escolha? Se, como resulta 
da análise de Bergson, em cada um dos momentos da duração não se pode, a rigor, falar em "dois" motivos ou alternativas "reciprocamente exteriores", como falar em escolha? Deixando de lado a distinção de Schopenhauer entre o caráter "inteligível” e o caráter "empírico", assim como a distinção bergsoniana paralela entre o Eu "profundo" e o Eu "superficial”, a vontade, o querer e as açóes aparecem em ambos como um suceder de voliçóes, as quais, se, por um lado, não poderiam ter sido outras do que efetivamente foram, também não sâo resultantes, nem são tornadas necessárias, pelo que quer que seja (são imprevisíveis) e, em particular, náo são resultantes de uma escolha livre.

SILVA, Hélio Lopes da. Freedom of choice in Bergson and Schopenhauer. Tans/form/açâo, Marília, v. 40, n. 1, p. 25-50, Jan./Mar., 2017.

ABSTRACT: I show in this paper that Schopenhauer and Bergson, although approaching the problem of free action from opposed philosophical standpoints, agree in characterizing human actions in a way which is neither determinist nor compatible with the liberum arbitrium thesis. Schopenhauer, although mistakenly trying to demonstrate the necessity of such actions, is obliged to recognize then as grundlos and unpredictable. Bergson, although intending to show such actions as free, in the end admits that they are not a matter of a reasonable choice. It is this unexpected agreement between both philosophers on the problem of the freedom of human action that will be explored in this paper.

KeYwords: Schopenhauer. Bergson. Freedom. Determinism. Choice. Prediction.

\section{REFERÊNCIAS}

BERGSON, H. Essai sur les données immédiates de la conscience. Paris: PUF, 1967.

FRANÇOIS, A. La volonté chez Bergson et Schopenhauer. Methodos, 14 abr. 2004. DOI: 10.4000/methodos.135. Disponível em: <http://methodos.revues.org/135. Acesso em: 14 dez. 2011.

GLOCK, H. J. Schopenhauer and Wittgenstein: language as representation and Will. In: JANAWAY, C. (Ed). The Cambridge Companion to Schopenhauer. Cambridge: Cambridge University Press, 2009. p. 422-458.

HUSSERL, E. Vorlesungen zur phänomenologie des inneren zeitbewusstseins. Freiburg: Max Niemeyer, 1928.

KANT, I. (KrV). Kritik der reinen Vernunft. Frankfurt: Suhrkamp, 1974.

SCHOPENHAUER, A. (WWR) The world as Will and representation. Tradução de E. F. J. Payne. New York: Dover, 1969.

. (WWV) Die Welt als Wille und Vorstellung. Frankfurt: Insel, 1996. 
(LV) Prize essay on the Freedom of the human Will. In: The two fundamental problems of ethics. Tradução de D. Cartwright e. E. Erdman. Oxford: Oxford University Press, 2010. p. 35-118.

Recebido em 08/09/2016

Aceito em 15/12/2016 
SILVA, H. L. 